\title{
PSYCHOLOGY
}

\section{Affect as a target of psychotherapeutic influence}

\author{
A. D. Tereshchuk \\ Kostiuk Institute of Psychology of the NAPS of Ukraine, Kyiv, Ukraine \\ Corresponding author. E-mail: tereschuk2011@meta.ua
}

Paper received 23.11.19; Accepted for publication 11.12.19.

\section{https://doi.org/10.31174/SEND-HS2019-213VII35-17}

\begin{abstract}
The article formulates the main ideas regarding the practical value of affects in psychological therapeutic practice. The modern views on affect psychotherapy and understanding of affect localization in a personality structures are presented. The basic affective systems are considered, which are the foundations for relations with care-givers and the whole world and determine, as a consequence, a person's identity and character. An affect occurrence and its integration into decision making, its importance for personal experience and human life arrangement are analyzed. The study on the concept of affect allows us to understand better the conscious and volitional processes, a person's behavioural structure and mechanisms, human motivation.
\end{abstract}

Keywords: affect, feelings, affective systems, intra-psychic structures, psychotherapy.

Introduction. Affects, being related to sensory sensations and contacts, are vital aspects of our functioning and orientation in the world. If consider affects from this point of view, they become an important focus in psychotherapy. Depending on how closely we relate to other people and understand a situation, our affects are what drive us to pursue our own interests and needs, an expression of what is going on between us, not separately with a client and a psychotherapist. Seeing an affective process as a symbol can lead an individual to a deep understanding of his/her life and his/herself.

A brief overview of the publications. Affects have central and important place in our mental lives and interpersonal relationships. In his earlier writings, Sigmund Freud equated affects with mental energy as a source of motivation (1894). He regarded them as manifestations of unconscious pursuits (1915b, p. 152) and concluded that affects serve as warning signals that operate in tandem with protections. In more recent studies, affects are understood as conflict-free ego functions (Emde, 1980a, $1980 \mathrm{~b})$, as the primary driving forces of a motivational system underlying the structuring of instinctual drives (Loewald, 1978, Kemberg, 1982).

Strong affects completely capture a whole person and all his/her vitally important behaviour. Without thinking about consequences of his/her actions, a person focuses only on what pushes him/her to them. And thereby, the person resings him/herself into the power of affect. "Do not allow affect to break into the sphere of actions, and you will overcome affect" [3, p. 45]. At affects, particularly sharp changes are observed in consciousness; it becomes narrow and is limited to a small number of representations and perceptions closely associated with the experienced emotion. During very strong affects, a person's usual attitudes, the nature and content of objective reality reflections are often rebuilt and dramatically changed; many phenomena and facts are perceived differently than usually, are shown in a new light, previously established personal attitudes are broken [6].

The affective process can often become an object for contemplation, leading to development of an individual's abilities to note in own inner world something unnoticed previously, so the individual becomes more empathetic and compassionate to others. This gives him/her the ability to be in contacts with other people. Awareness of an affective process can be considered simultaneously as a signal and a symbol that informs about the wise course of action in an existing situation [5]. "Whenever any affect of mine awakens, its awakening deserves my full gratitude, as it is my instant way of helping me. Everything that I experience deserves my full love, for it is precisely through such an experience that I save my life" (Dorsey J.M.). This quote well illustrates the mature attitude and handling with affects and can serve as a kind of message for clients in therapy [1, c. 4].

Results and discussion. Feelings are of great importance for psychotherapy. If a psychologist can "reach out" to emotions and affects and stimulate their development and manifestation in therapeutic conversations, namely this becomes the basis for successful psychotherapy. If the psychologist succeeds, then the psychotherapy achieves successfully its objectives. Indeed, personal internal links are formed through emotions and affects, thoughts, memories; so, not only an event is experienced, but also an experience of oneself in this event [4, c.11].

The psychological therapy means a client's successful movement from his/her abnormal functioning as a personality to healthy life (John F. Clarkin, Frank E. Yeomans, Otto F. Kernberg, 2006). This is achieved by normalizing an individual's experience of relationships with significant others, stable client-therapeutic interactions, as well as by formation of mature ways of dealing with both positive and negative affects. The successful therapy helps develop numerous methods of actions, defences and patterns, various mature strategies and techniques that reduce distress intensity and return the client to a full conscious assessment and analysis of his/her experiences. Psychological therapists' task also includes their ability to imagine what is happening with their clients, in terms of affect experiencing by the clients, recognizing of their true needs and intentions, and understanding of their behaviour. For example, a fairly good mother interprets a theft of her pocket money by her child, not as a sign of psychopathology, but as a communicative message about unmet needs and a possible lack of attention. This parent ability is equal to a psychotherapist's ability to imagine a 
patient's cognitive and affective mental states, and can be called as "creation of an internal model of an another person's consciousness" (Fonagy, P. et al., 2002) [1].

The psychotherapeutic view on affects is different from the classical one, where affect is mainly understood simply as a strong emotional "discharge". From the point of view of classical psychology, affect is a short-term, very vivid emotional reaction, accompanied by typical behavioural manifestations that are hardly controlled by intellect. At the time of affect, perception of reality is usually changed (Freud, Jacobson, Izard, Mahler, Emde, Stern, Kernberg, Krause). From the standpoint of psychotherapy, affects are complex intra-psychic structures that include motivational, somatic (affects directly influence on our physiology: palpitations, blanching, redness; bodily manifestations), expressive (affects are expressed not only verbally, but with gestures, facial expressions, postures), communicative (this is the earliest form of communication between a mother and her baby) and cognitive (affects are connected with mental activities, with event assessment) components. The cognitive element is present even in the brightest moments of affect and in the most severe manifestations of regression (F. Tyson, A. Compton, P. Knapp).

Affect has two components (in its internal structure): the static component, manifested in the form of an assessment, interpretation of what is happening (bad or good), and the dynamic one as an impulse toward good; movement from bad to good. In therapy, the question "What do you feel?" is very important, because it makes possible to focus on static and dynamic components during work with a client. The questions "Where do you want to move?", "What do you want to achieve?" enable both a therapist and a client to focus on the client's needs. After all, affects are the vehicles for needs. Therefore, it is so difficult to work with alexithymia, since a person does not know what he/she wants. Such clients have labels for their emotions, do not know how to reflect over them and experience certain distress, not even knowing about it.

The earliest level in the emotional system is formed from primitive affects. They are innate, transmitted at the genetic level and are universal for all mammals. They are actively appears at the first 2-3 years of life. Primitive affects are intense, global (encompass all mental processes); they form and create characteristic behavioural patterns (joy, fear) and are universal for all cultures. In general, basic affects exist almost all human life. Affect arises under influence of certain fixed stimuli. These emotional reactions block a specific part of the brain. Now, the neurobiology of affect is a very actual topic. As an individual grows older, derivative affects appear; these are basic, primitive affects undergone cognitive intellectual processing. This takes place due to learning, when reflex links are formed (a child is punished for manifestations of some feelings, he/she is shown what is allowable and what is not), curiosity becomes more restrained, thinking is turned on (why are we sad? what feeling am I perceive? - reflection is developed), cognitive processing takes place. The next level is the level of emotions and feelings. The difference between emotions and feelings is that feelings are more stable and attached to a specific object (love for mother, homeland), and emotions are reactions here and now to changes. Mental components dominate physiological and behavioural elements; emotional behaviour can be hidden, which means reflected, but not manifested. And the last level is moods. Mood means generalization of affects concerning to the whole objective world for a rather long time; it is an assembly of all emotions.

Neurobiological studies confirm that primary affects are activated in the subcortical zones of the brain, which are identical anatomically, neurochemically and functionally. Affects are transient variables that tell people how to deal with the issues of survival. Various positive affects indicate that all living things tend to return to "comfort zones" that support survival, while negative affects reflect "discomfort zones" indicating threatening situations. They are an inherited tool for survival; it is evolutionary memory containing important information in encoded form transmitted by the genome in its pure form (like primary thought processes) and then cultivated by basic learning mechanisms (secondary processes), as well as high-order thought processes (tertiary processes) [2].

Affects can be represented as a part of emotional continuum extending from primary, basic forms to their secondary configurations, and further to emotions, feelings and moods, where mental, cognitive aspects dominate physiological and behavioural manifestations (A. Yezhov).

Jaak Panksepp identified seven basic (innate, genetic) affective systems that are the foundation for relationships with care-givers and the whole world and, as a result, determine a person's identity, character and sexuality [7]. These are evolutionarily programmed ways of helping oneself. They are focused on the best adaptation of individuals, species; and, accordingly, they are related to the issues of survival.

1. Search / desire system. This is a motivational system of excitations, the main source of "vital energy", also called "libido". Searches fill the mind with interest and motivate the body to freely seek, strive and desire. As for humans, this system operates and maintains curiosity, including solving everyday and highly intellectual problems. It is suppressed by drug addiction, chronic stress and diseases associated with depressive conditions. Excessive activity of this system can provoke provocative and impulsive behaviour. This system is controlled by the medial forebrain bundle and is neurobiologically linked to the dopamine excitatory system. The search system provides the resources necessary for survival. It supports learning through the insatiable thirst for knowledge. It causes a feeling of satisfaction from solved tasks and reduces depressive effects and dysphoria at drug addiction.

2. Rage / anger system. If the search system cannot be activated, rage ensues. Anger comes as a result of restrictions and limitation of a freedom to act. It is accompanied by excitation of the brain from the medial amygdala, the hypothalamus to the gray matter of the brain; the excitation can cover a fairly large area. Rage comes in very close contact with the fear system and interacts neurophysiologically with it (shock-response). It gives an impetus to aggressive behaviour for self-defence. Stimulation of the aforementioned brain parts can provoke sudden strong attacks of anger even if external stimuli are absent. 
3. Fear / anxiety system. Appeared fear helps us to avoid danger, to protect ourselves from pain and destruction. The "hit or run" system is activated in this case. If such impetuses are suppressed, then this leads to a "frozen reaction".

4. Passion / sex system. This system is closely associated with sex hormones, sexual desire, estrogen for women and testosterone for men. Oxytocin promotes women's sexual readiness, as well as trust and confidence, and testosterone does men's persuasiveness and, possibly, envy. These brain chemicals contribute to the creation of gender-based sexual preferences. The dopamine-active search system is involved in the selection of sexual and other incentives.

5. Care / parental care system. It is triggered by oxytocin, prolactin growth and progesterone reduction. Such a hormonal inversion leads to the fact that mothers have a strong desire and need to take care of their children. Brain evolution provides a self-defence system so that parents (usually mothers) take care of their offspring. Some chemicals involved in the reproductive system, such as oxytocin, are reoriented into a link of maternal care custody and social development - confirming the fact that there is a close evolutionary link between a woman's sexual satisfaction and motivation to become a mother.

6. Grieving / separation panic system. Initially, this system was called the "panic system", but only a few scientists understood the terminology that describes the primary processes. Therefore, the name was changed to "grieving", which is more consistent with third-order processes. All living things cry when they are lost, making it clear that they need attention, they experience intense anxiety. It is also worth mentioning that panic attacks are signs of this system activation (separation panic). Panic attacks can reflect a sudden endogenous loss of a security feeling (an extreme manifestation of separationanxiety) rather than a sudden fear. These links appear at experiencing of grief and sorrow, accompanied by low opioid brain activity.

7. System of games / social inclusion and struggle. Games are constantly accompanied by positive emotions, joy, with certain signals. For example, even rats make a squeak that resembles laughter. They are also important for social role identification, it is possible to learn social rules and cultivate social interactions by plying.

Thus, these systems show importance of understanding affects in terms of norm and pathology [2].

We propose the exercise that helps understand how affects are localized in all personality structures. The first task is to draw (describe), in pairs, a picture of your life from birth to here and now; to remember throughout your life the moments of maximum activation of any of these systems; to recall an episode from childhood or adulthood (preferably from childhood).

Questions:

1. What activated this system? What irritants, contexts, situations activated it?

2. Describe your behaviour and physiological reactions at activation of this system?

3. What knowledge about yourself and the world around you came from this experience?

4. How does this experience help you and how does it influence now?
The second task is to find, in a pair, common processes, similar moments for each item in the system and investigate them; to analyze, identify, determine what are the fundamental basic units that organize our experience, our life, psyche. Each group examines each system, and a common discussion is proposed.

Search / desire system. What activated the system? (getting what I want). How did this manifest? (behaviourally or physiologically). What did you learn about yourself? Therapy is based on this system.

Rage / anger system. Describe by step-by-step, what did you do? What are your memories? How is it related to you? It is not fear that is terrible, but that which precedes it. Fear of be frozen (be invisible) lead to actions.

Fear / anxiety system. What are signals, markers of this system? (gaze fixation, clenched fists, jaws, biting). What did you learn about yourself, about the world? A meeting with rage is a meeting with oneself, with one's strength. In psychotherapy, working with an angered client is very good if rage is directed to changes (I will prove). It gives a very big energy.

System of games / social inclusion and struggle. What activates this system? Markers: easing of tension (physiological), relieved tension, getting away from something (from pain, commitments). If a person does not know how to play, he/she has nothing to do at the psychotherapy state of deep consideration (he/she cannot identify $\mathrm{him} /$ herself with someone else). The game evokes a subpersonality of an inner child, switching to an eased state without responsibilities.

Care / parental care system. It activates caring behaviour to help others: signals obtained from a child are an expression of the need for caring (you do not want to take care of an evil child).

Grieving (panic) / separation system. Panic, separation panic: it's hard to let someone go (it is impossible to quit me).

Passion / sex system. This system is activated in the first years of life. What is the first memory of passion / sex? (passion for parents, parent-child relationships, attraction to a therapist).

During the psycholocal several questions help reveal affective experience better.

For example, the affective process can be monitored with the following questions:

- What emotions do you feel when you talk about an examined situation?

- What do you feel in your body when you talk about it?

Creative aspects of emotions can be studied also:

- Verbal descriptions: I wonder what you are experiencing right now.

- Visualization: what colour does this feeling have? how big is it? does it have a shape?

- Body sensations: where do you experience it in your body?

- Movements: what does this emotion want to do?

- Art: could you paint your feeling?

Movement to an unfinished situation is revealed through the following questions:

- Did you feel this emotion when you were a child? 
- How old were you when you first experienced this feeling?

Return to the present with new understanding of an examined situation is revealed like this:

- How is the current situation different from the one existed in childhood?

- $\quad$ Do you see new opportunities for how you can act in the examined situation? [5].

Affects become drivers of desires and needs, built into the system of human relations with the world, based on the experience of early object relationships. That classic therapeutic question, "What do you feel?", becomes an important step towards "What do you want to achieve?" At therapeutic sessions, this is very clearly seen when people, by naming their feelings, already indicates their therapeutic needs (consciously or not consciously). A psychotherapist offers emotional support as long as it is needed and helps client to use their own resources.

Thus, we can say that:

- $\quad$ affects are not just processes of emotional easing of tension, they are complex intra-psychic structures that include motivational, somatic, expressive, communicative and cognitive components;
- there are no "pure" affects without cognitive content;

- $\quad$ affects act as drives of desires and needs;

- $\quad$ affects are linked with object relations; there is no any "affect without an object";

- affects reflect and complement a client's internal object relations;

- affects are part of a person's emotional system, and the emotional system means a subtle tuning towards survival.

Conclusions. Affects are vital aspects of our functioning and orientation in the world. They become an important focus in psychological therapy, because there we encounter everything that we name as fear, shame and guilt, sadness, gloom, stubbornness, anger and aggressiveness. Therapists' task is to imagine what is happening with their clients, in terms of affect experiencing by them, recognizing of their true needs and intentions, when and why they show particular behaviour. Affects must be recognized, their intensity assessed, they must be metered and manifested at the right time, appropriately apprehended and retained. A psychotherapist teaches the art of affect awareness, and psychological therapeutic contact is the main tool.

\section{ЛИТЕРАТУРА}

1. Ежов А. Аффекты: семь подходов в обращении [Э. ресурс]

https://psy4psy.ru/affect?fbclid=IwAR1R2nWuqpOtm9i9c01Dqw17IUdJntd3pUfOE25XiQvj01WkLAb270JwEs

2. Ежов А. Базовые эмоциональные системы: взгляд современной нейробиологии https://psy4psy.ru/affect_sustems

3. Зелинский А.Ф. Осознаваемое и неосознаваемое в преступном поведении. Высшая школа. Изд-во при Харьк. ун-те. Харьков. 1986. 167 с.

4. Лэнгле А. Эмоции и экзистенция. 2-е изд., Пер. с нем. Х. Изд-во гуманитарный центр, 2011. 232 с.

5. Сорокин А. Аффективный процесс в гештальт-терапии. $\begin{array}{llll}\text { Питер Х. } & \text { Коул. } & \text { [Э. } & \text { ресурс }]\end{array}$

https://gestaltclub.com/articles/obsaa-psihologia/9879affektivnyj-process-v-gestalt-terapii-piter-h-koul

6. Черчен А. Генез понятия «аффект» в психологии, психиатрии, праве [Э. https://cyberleninka.ru/article/n/genez-ponyatiya-affekt-vpsihologii-psihiatrii-prave/viewer

7. Jaak Panksepp, Ph. D., (2010). Affective neuroscience of the emotional BrainMind: evolutionary perspectives and implications for understanding depression.

8. Tereshchuk A.D., (2017). Peculiarities of affects in personal psychological development // Science and Education a New Dimension: Humanities and Social Sciences, V(24), Is. 146. P. 43-46.

\section{REFERENCES}

1. Ezhov A. Affektyi: sem podhodov v obraschenii [E. resurs] https://psy4psy.ru/affect?fbclid=IwAR1R2nWuqpOtm9i9c01Dqw17IUdJntd3pUfOE25XiQvj0lWkLAb270JwEs, Russia.

2. Ezhov A. Bazovyie emotsionalnyie sistemyi: vzglyad sovremennoy neyrobiologii [E. r resurs] https://psy4psy.ru/affect_sustems, Russia.

3. Zelinskiy A.F. (1986). Osoznavaemoe i neosoznavaemoe v prestupnom povedenii. Vyisshaya shkola. Izd-vo pri Hark. un-te, Kharkov, Ukraine.

4. Lengle Alfrid. Emotsii i ekzistentsiya. (2011). 2-e izd., Per. s nem.- H. Izd-vo gumanitarnyiy tsentr, Kharkov, Ukraine.

5. Sorokin A. Affektivnyiy protsess $v$ geshtalt-terapii. Piter $\mathrm{H}$. Koul [E. resurs] https://gestaltclub.com/articles/obsaapsihologia/9879-affektivnyj-process-v-gestalt-terapii-piter-hkoul (accessed January 19, 2018).

6. Cherchen A. Genez ponyatiya «affekt»v psihologii, psihiatrii, prave [E. resurs] https://cyberleninka.ru/article/n/genezponyatiya-affekt-v-psihologii-psihiatrii-prave/viewer 